\title{
Spiritually Oriented Couple, Marriage and Family Therapies
}

\author{
Şeyda Çetintaş \\ Fatih Sultan Mehmet Vakıf University
}

\author{
Halil Ekşi $^{2}$ \\ Marmara University
}

${ }^{1}$ Şeyda Çetintaş, Ph.D., Graduate Research Assistant at Fatih Sultan Mehmet Vakıf University, Department of Guidance and Psychological Counseling, Turkey. E-mail: scetintas@fsm.edu.tr.

${ }^{2}$ Department of Educational Sciences, Guidance and Psychological Counseling, Marmara University, Istanbul, Turkey. E-mail: halileksi@marmara.edu.tr

Corresponding author:

Şeyda Çetintaş

\section{E-mail:}

scetintas@fsm.edu.tr

eISSN: 2458-9675

\section{Received Revision:}

11.11.2019

Revision:

27.12.2019

Accepted:

8.02.2020

CCopyright 2020

by Author(s)

\begin{abstract}
In this review, it is aimed to focus on the integration of spirituality into familyoriented psychological help processes. To conceptualize the reflection of spirituality on the family system more clearly and to make sense of the spirituality-family relationship, the issue of spirituality was examined in specific processes such as in the relationship between parents and children, between spouses and in the transition process from adolescence to late age. The paradoxical nature of spirituality in family relationships was emphasized. For this purpose, spirituality was discussed both as a source of problems and as a source for solutions in family relations. Spiritually oriented psychological clinical help is an emerging field in Turkey. Seeing that spirituality is such an important issue in family relations and marriage, it is aimed to bring a family-focused approach to the spiritually oriented psychological help process. So, by addressing ethical issues, this review aims to off er a new perspective to field practitioners working with couples and families in clinical practice.
\end{abstract}

Keywords: Spirituality, Couple, Marriage, and Family Therapies, Psychological Counseling

\section{Manevi Yönelimli Çift, Evlilik ve Aile Terapileri}

Öz

Bu çalışmada, maneviyat konusunun aile odaklı psikolojik yardım süreçlerine entegre edilmesine odaklanılmıştır. Maneviyatın aile sistemine yansımasını daha net bir şekilde kavramsallaştırabilmek ve maneviyat-aile ilişkisini anlamlandırabilmek için bu konu ebeveyn-çocuk ilişkisi, eşler arası ilişki, yaşlılık dönemine geçiş gibi spesifik süreçler içerisinde incelenmiştir. Maneviyatın, bu süreçlerdeki paradoksal doğası vurgulanmış ve maneviyat konusu hem sorunların kaynağı olabilme hem de sorunlara çözüm olabilme özelliğiyle tartışılmıştır. Manevi yönelimli psikolojik danışma ve terapi Türkiye'de son zamanlarda çalışılan, güncel bir alandır. Maneviyatın, aile ve evlilik ilişkilerindeki önemi göz önünde bulundurularak, bu bölümde manevi yönelimli psikolojik yardım süreçlerinde, aile odaklı bir yaklaşımın tanıtılması hedeflenmiştir. Bu nedenle, etik konulara değinilerek, klinik uygulamada çiftler ve ailelerle çalışan alan uygulayıcılarına yeni bir bakış açısının sunulması amaçlanmıştır.

Anahtar Kelimeler: Maneviyat, Çift, Evlilik ve Aile Terapileri, Psikolojik Danışmanlık

Citation: Çetintaş, Ş., \& Ekşi, H. (2020). Spiritually oriented couple, marriage and family therapies. Spiritual Psychology and Counseling, 5, 7 - 24. https://dx.doi.org/10.37898/spc.2020.5.1.096 


\section{Spiritually Oriented Couple, Marriage and Family Therapies}

For professionals, it is more difficult for some subjects to be included in the psychological help process than for other subjects that are discussed in the counseling session. Spirituality and religion seem to be one of these challenging areas and many professionals do not know what to do when the phenomenon of spirituality manifests itself in the psychological help process (Helmeke \& Bischof, 2002). Although spirituality is a highly related area to the individual, spiritual issues are often overlooked or avoided in marriage and family therapy and, even spirituality may be considered as more taboo than death (Prest \& Keller, 1993). It would not be wrong to say that psychological counselors and therapists have various reasons for their hesitation about spirituality. As a part of the training that the professionals received, not imposing their values and beliefs on their clients and respecting the clients have been accepted as basic principles (American Association for Marriage and Family Therapy (AAMFT), 2015). Some professionals may be hesitant because they have difficulty in distinguishing religion from spirituality and defining these two concepts (Marterella \& Brock, 2008). For some professionals, this hesitation is due to the lack of training on how to integrate spiritual issues into the psychological help process properly and the lack of counselors' selfconfidence in this matter (Helmeke \& Bischof, 2002).

In today's society, the vast majority of individuals and families, whether they are part of any religion or not, have adopted personal experiences, in which they can express their spiritual values. These spiritual beliefs that individuals possess may affect their experience of suffering, the meaning of the symptoms they experience, their ways of talking about their problems and sufferings, the causes of their suffering and their belief in sufferings' future course, their ways of dealing with their troubles, their attitudes towards the psychological counselor and therapist, the treatments they seek, and their preferred ways to solve problems (Walsh, 2009c). In addition to all these, the individuals' spiritual experiences can be the source of the troubles they live. In other words, stress factors of spiritual origin may lie under the emotional and physical problems experienced by the clients (Smith \& Harkness, 2002). In this case, it seems meaningful for professionals to consider clients' spiritual belief systems to better understand the people they work with (Prest \& Keller, 1993). Considering that many of the individuals seeking help for their physical, emotional and interpersonal problems are also in spiritual distress, it seems to be a necessity to participate in the spiritual dimension of the human experience to understand the needs and suffering of the clients, to help them recover, and to grow (Walsh, 2009c). Since the spirituality is an important part of human experience and has indirect and direct effects on the counseling process, this review aims to address the issue of spirituality within the family system and in the process of couple and family therapy. 


\section{Spirituality in Family Life}

Spirituality is a powerful dimension of human experience, which includes transcendental beliefs and practices and promotes human prosperity, commitment, and search for meaning (Walsh, 2009b). The fastest expression of spirituality, which is relational in nature, manifests itself in family bonds (Walsh, 2012). Family process research has shown that transcendental values support healthy family functioning (Abbott, Berry, \& Meredith, 1990). Family members need a value system that goes beyond the limits of their knowledge and experience in order to accept the risks and losses they will experience as an inevitable part of their closeness and love they share (Walsh, 2006). Having a spiritual world view guides the individual and the family unit throughout the course of life and generations, provides greater values and goals, guides daily actions and relationships, and strengthens the potential to overcome troubles (Walsh, 2009b). The individuals can thus see things from a broader perspective, which makes things more meaningful, which increases their hopes, and which strengthens their bonds with other people and common humanity (Walsh, 2006, 2012).

Recent studies have shown that spirituality has a significant impact on family functioning and satisfaction with family life (Abbott et al., 1990; Bailey, 2002). A meaningful relationship with God may positively affects relationships with family members (Dollahite, Marks, \& Goodman, 2004) and these individuals may feel closer to their families and look to the future with more hope (Walsh, 2009c). Research on religious rituals and practices reveals that the family's religious activities are "a potentially unique pathway to facilitate family cohesiveness" (Mahoney, Pargament, Tarakeshwar, \& Swank, 2008, p. 590). For example, regular involvement in family prayer and participation in religious services offer parents the opportunity to convey issues such as apology, hope, and shared goals in a context controlled by an authority that has a power even over parents (Mahoney et al., 2008). In their research on how religious beliefs and practices affect family satisfaction, Abbott et al. (1990) explained that religiousness contributed to family life in five different ways. These ways were defined as "(i) by enhancing the family's social support network, (ii) by sponsoring family activities and recreation, (iii) indoctrination in supportive family teachings and values, (iv) by providing family social and welfare services, and (v) by encouraging families to seek divine assistance with personal and family problems" (p. 443). In this research, while divine intervention and social support were found to be the best determinants of family satisfaction for the parents of children in preschool and school-age, a different scheme was found for the parents of adolescents. For adolescents, family teachings, activities, social support services were found to be more important for satisfaction with family life. The religious beliefs and activities of the participants reinforced the perception that religion was important in promoting 
social support and sacred intervention, as a result of which social support and divine intervention increased family satisfaction. Social support was found to be the most important factor in family satisfaction. The participants stated that most of their friends were also connected to the same religion with them and that they often socialize with them and receive support. The other important factor, divine intervention, was found meaningful because, in participants, it created the perception that "God is a reality and that this divine being is interested in the family well-being and is effective in facilitating it" (Abbott, 2001, p. 447).

The family is at the center of events attributed to sacred values that include events such as the birth of a new individual, stepping into the adult society, marriage, loss of a loved one (Walsh, 2012). Experiences such as stepping into marriage in the presence of the divine power, sharing the birth of a baby that is a symbol of mutual love, and confronting an eternal separation with death are things that many people attribute sacred and spiritual values. In this respect, the family has a spiritual dimension due to the nature of being a family (Walsh, 2012). When we consider the family as a system, it is important to conceive the members within this system and the different dynamics that will arise between these members. In order to conceptualize the reflection of spirituality on the family system and to make sense of the spiritualityfamily relationship, this issue will be examined in specific processes such as in (i) parent-child relationship, (ii) relationship between spouses, (iii) transition process from adolescence to late age.

\section{Spirituality in Parent-Child Relationship Processes}

In recent years, a lot of research has been done to examine the effects of spiritual beliefs, practices and being part of religious communities on parenting styles and parent-child relationship (Mahoney et al., 2008; Marks, 2004; Snarey \& Dollahite, 2001; Snider, Clements, \& Vazsonyi, 2004). In these studies, religiosity was found to be associated with positive parenting and better child adjustment (Mahoney et al., 2008), and increased parental involvement (especially father involvement) (Marks, 2004). For example, a study with adolescent mothers showed that mothers with high participation in religious activities had higher self-confidence, lower depression scores, lower risk of child abuse, and higher occupational and educational accomplishment (Carothers, Borkowski, Lefever, \& Whitman, 2005). In the same study, the frequency of internalization and externalization behavioral disorders observed at the age of 10 was found lower in children whose mothers were more religious (Carothers et al., 2005). It was also shown that religious parents had a closer relationship with their children, paid attention to the child supervision, and they were perceived by their children as having effective parent characteristics (Snider et al., 2004). Similarly, in a meta-analysis study, parental religiosity was found to improve the effective parenting 
skills, which in turn indicated a low risk of behavioral disorders in childhood and low alcohol/drug use risk in adolescence (Mahoney et al., 2008).

Contrary to these findings, there have also been studies indicating that religious families tend to have a more positive attitude towards physical punishment and tend to punish their children through physical means (Mahoney et al., 2008; Snider et al., 2004). For example, it was observed that parents who had connections with conservative Christian groups were closer to authoritarian parenting attitudes and tended to hit their children by believing in the importance of physical punishment (Mahoney et al., 2008). It was also seen that religious parents were perceived by their children as more authoritarian/oppressive parents (Snider et al., 2004). For children to internalize similar values with their parents, it seems important for families to display their spiritual values and religious beliefs consistently in family life and their interactions with children (Marks, 2004). In other words, it is important for parents to practice religious teachings that they advise and share common spiritual experiences with their children to increase family intimacy and loyalty (Marks, 2004). However, family prayer considered an obligation can sometimes have adverse effects. In this case, internal resistance can occur in children against religious family practices and tensions may arise between children and families (Marks, 2004). Based on these studies, it can be said that spirituality is an important issue in the relationship between parents and children.

\section{Spirituality in the Relationship Between Spouses}

Religiosity and spirituality have been found to be factors that reduce the risk of divorce and facilitate the marriage process (Mahoney et al., 2008). For this reason, it seems important to discuss religiosity and spirituality in the processes of the relationship between spouses. In this respect, it is striking that many studies are examining the role of religiousness in conflicts between spouses (Dudley \& Kosinski, 1990; Myers, 2006). For spouses, having similar religious belief systems and practices were found to be associated with high marital satisfaction and low risk of divorce (Myers, 2006). Also, research shows that couples' religious tendencies help them to develop virtues preventing conflicts. For example, in their study on the effect of religiosity on marriage, Dudley and Kosinski (1990) emphasized that religiousness reinforced ideas such as "think of the needs of others, be more loving, be more forgiving, treat each other with respect, and resolve", which in turn made couples more tolerant to each other and strengthened their marriage (p. 82). Considering the importance of virtues examined in this study, it might be evaluated as a constructive option for professionals to help couples develop such virtues that can prevent conflict in their relationships.

Another issue that can be addressed at this point is infidelity. Since religious marriage ceremonies accept sexual monogamy as a sacred promise and forbid extramarital affairs, such religious messages can trigger a sense of prohibition and 
guilt, and prevent sexual relations out of marriage (Mahoney et al., 2008). Also, individuals may be more willing to explore sexuality within a marriage relationship and enjoy sexuality (Mahoney et al., 2008). On the other hand, religious individuals who see sexual activity as an essential component of a well-functioning marriage can seriously worry if their sexual activity is reduced (Mahoney et al., 2008). Another issue that can be addressed in the context of the relationship between the spouses and spirituality is interfaith couples. Until recently, marriage between individuals of different religions has been a highly controversial subject. Parents have been prevented their children from marrying individuals of different religions. Recently, with the weakening of the strict boundaries between religious groups, marriage, which can be described as a voluntary social agreement between two people, has also begun to move to a cross-religious dimension, and in recent years there has been an increase in the number of interfaith marriages (marriage between couples with different religions) (Waite \& Lewin, 2010). Yet, some situations pose a risk for marriage to fail for interfaith couples, such as different religious beliefs which make the relationship difficult and cause conflicts, belief that one religion is superior to other, less tolerance to differences, and family disapproval (Walsh, 2009c).

\section{Spirituality in the Process of Transition from Adolescence to Late Age}

Families are interconnected, holistic, and dynamic systems (Klein \& White, 1996). That is, each member of the family has its system, which is shaped by different dynamics, and these systems are linked to the systems of other family members and interact with each other and affect each other. Within the family system, each member who is part of the system with advancing age steps into a different period and systematically all individuals are affected by this situation. For example, with the advancing age, the so-called little ones of the family take steps towards adolescence and young adulthood. Especially young adults, those who go to university, can move away from their family's religious upbringing and begin to question their family's religious traditions more actively, or abandon their family's religious traditions altogether (Walsh, 2009c). Marcia (1966) defines 4 types of identity for the formation of ego identity for youth seeking an identity: (i) identity achievement, (ii) moratorium, (iii) identity foreclosure, (iv) identity diffusion. In this model, the most important criterion taken into consideration in placing the individual in a certain identity category is the degree of crises and commitment experienced (Kacerguis \& Adams, 1980). "Crisis refers to the adolescent's period of engagement in choosing among meaningful alternatives; commitment refers to the degree of personal investment the individual exhibit" (Marcia, 1966, p. 551). According to these criteria, the acquisition of identity involves going through a crisis period and developing commitment to a profession and ideology (eg., religion) based on one's evaluations (Marcia, 1966). Various quests accompany the crisis period until a commitment is gained. Many 
young adults explore other spiritual pathways in search of meaning, belief, and commitment (Walsh, 2009c). It is quite an expected result that other members of the family will be affected by this period which is experienced by young people who are members of the family system. Choices made by children can be interpreted by parents as the rejection of family and their family inheritance (Walsh, 2009c), which in turn results in conflict between family members.

The period from middle age to late ages is a period in which a remarkable growth occurs in spirituality, with family members' struggles about the meaning of life, the need for protection from the painful feeling of uncertainty and insecurity, and the death of their loved ones (Erikson, Erikson, \& Kivnick, 1986; Lyons, 2005). In parents' chronic illnesses, despite the increased physical regression and care burdens, a deeper sincerity and spiritual bond may develop between parents and children who care for them (Walsh, 2009c). For example, in a study conducted with individuals responsible for the care of elderly people with dementia, the vast majority of caregivers stressed that spiritual resources are particularly important in their experience during this process (Smith \& Harkness, 2002). During the therapy, family therapists can provide caregivers with the opportunity to make sense of the positive or negative spiritual experiences, which may contribute to the well-being of their clients; and spirituality can open new resources for the caregiver and therapist to use if the disease progresses and demand for care increases (Smith \& Harkness, 2002). With advancing age and retirement, active participation in the faith community, prayer, meditation, spending time in nature, and serving others can become increasingly important, so individuals can change their priorities and devote more time to spiritual life (Walsh, 2009c). Undoubtedly, the wisdom of the elderly deepens with increasing spirituality (Walsh, 2009c).

\section{Spirituality in the Couple, Marriage, and Family Therapy Process}

\section{Dynamic Nature of Spirituality on Family Life}

According to the system perspective, there is a mutual interaction process between spirituality and the family. Each family forms its spiritual structure that will continue by being transferred to the next generations in its own way (Walsh, 2012). Meaningful spiritual beliefs and practices strengthen family unity and the bond between members. With this empowerment, shared spiritual experiences further increase the faith of family members. On the contrary, harsh and oppressive spiritual beliefs and practices can injure family members, family spirit and family relationships, and family members who are damaged as a result of this injury may move further away from the family and their beliefs (Walsh, 2012). For example, parents who define themselves as religious may not consider the use of physical punishment appropriate for the form of parenting defined by their belief system and may refuse to use such 
a disciplinary strategy. On the contrary, different parents, who also define themself as religious, can see child discipline as a spiritual task and use physical punishment considering that it is necessary to draw strict limits on unacceptable child behavior. In such a situation, the child, who sees the consistency of the families' discipline attitude, maybe more obedient and adapt the situation (Mahoney et al., 2008). Also, adolescents, who evaluate their parents' physical punishment in a larger religious system, may consider the situation fair and accept the use of punishment (Mahoney et al., 2008). On the other hand, parents who impose heavy punishments because of their religious beliefs may experience difficulties in negotiating and communicating with their children, especially during adolescence; and may have children who will experience severe feelings of shame, guilt, fear, and be at risk of internalization disorders such as depression and anxiety (Mahoney et al., 2008). In this case, while the spiritual and religious values of family members affect the entire family system, the affected system also affects the spiritual values of its members.

For many of the clients, their spiritual stress may be a source of physical, emotional, and relational problems they experience (Walsh, 2009a). Given this dynamic relationship between family and spirituality, it seems inevitable to encounter such scenarios: "the religious and spiritual values of the client as a source of problems in the family system, the use of the client's spirituality as a source in dealing with problems in the family system, the family system affected by the client's spiritual crises, and crises in the client's spiritual belief system caused by problems in the family system". In this case, excluding spirituality from the client's system during the psychological help process can provide an incomplete picture of the client.

\section{Inclusion of Spirituality in the Clinical Practice Process}

"Most families and couples who come for therapy or counseling are seeking more than symptom reduction, problem solving, or communication skills; they are seeking deeper meaning and connections in their lives" (Walsh, 2009a, p. 31). In this search for meaning, trying to understand the clients' spiritual belief systems will help to gather more effective information about the forces that enable their current problems to arise and persist (Prest \& Keller, 1993). The reservations experienced by professionals about the inclusion of spirituality in the psychological help process are quite possible. While some professionals may be afraid that discussing spiritual issues with the client may disturb the client or make the client feel under pressure to admit to the principles of religion, for some therapists who have not yet defined what spirituality means to their lives, spiritual discussions with the client may trigger their spiritual questions (Smith \& Harkness, 2002). However, at this point it is important to realize that exploring the clients' relationship with their spiritual beliefs does not mean that they should speak about religious preferences, on the contrary, the process 
is about the beliefs and meanings that the clients place on their spiritual experiences (Smith \& Harkness, 2002).

Until recently, the concept of spirituality has been considered as off-limits in clinical training and practice, leaving many therapists uncertain about how to approach the client if the issue of spirituality comes to fore (Walsh, 2009b). However, spiritual difficulties and gaps in an individual's life and relationships may constitute to suffering and restrain positive growth (Walsh, 2009b). Thanks to the therapist's awareness of the importance of spirituality for spiritually inclined clients, many healing resources may become available for the therapy process (Griffith \& Griffith, 2008). In this case, it would not be wrong to say that the acceptance of spirituality as off-limits in the therapy process may result in ignoring many resources that can be used for the well-being of the client and presenting the therapist with a poor perspective in understanding the source of the problem.

The actual success in the therapy process depends on the therapist's ability to understand the client's belief and thinking system (Harris, 1998). The therapist's awareness of the problems caused by the destructive expression of spirituality is as important as the awareness that spirituality provides many healing resources for the therapy process (Griffith \& Griffith, 2008). The therapist should act in harmony with the client's belief systems, but should also challenge certain aspects of this system (Prest \& Keller, 1993). In doing so, the therapist's attempt to understand how spirituality will be the source for the solution is as important as understanding how the client's belief system provides resources to the problem (Prest \& Keller, 1993). At this point, the recent literature, with increasing spiritually oriented case examples, methods, and techniques, provides a rich resource to assist therapists and psychological counselors working with families or couples who want to bring their spiritual belief systems into the psychological help process.

\section{Discovering the Spiritual Dimension in Clinical Evaluation}

In recent studies, a spiritual perspective has been brought to the psychological help process in couple, family and marriage therapy and evaluation methods have been developed that can assist therapists in the clinical evaluation process (Anderson \& Worthen, 1997; Helmeke \& Bischof, 2002; Hodge, 2000; Prest \& Keller, 1993; Tanyi, 2006). Prest and Keller (1993) proposed various strategies to therapists for the purposeful use of myths and metaphors in the psychological counseling process, which belong to traditional and non-traditional spiritual belief systems, and presented these strategies on case examples. In one of these cases, the problems experienced by a couple trapped in a dysfunctional system due to their religious beliefs were redefined with a spiritual perspective and solutions were proposed within a spiritually oriented perspective (see Table 1). 
Table 1

Case Example

Ross (34) and Mary (33) came to therapy presenting his depression as the problem. Further assessment uncovered a number of problems, including Mary's compulsive overeating, drug abuse, recent suicidal gesture, and general depression; Ross's status as a dry alcoholic and unemployed iron worker; their 17-yearold son's heavy abuse of drugs and alcohol for the last year; Ross's and Mary's unresolved family-of-origin issues related to having grown up in alcoholic homes; and couple relationship issues, including painful pursuing and distancing patterns, control issues, and difficulty with sexuality. The spiritual solutions utilized by this couple had become part of their current problem. For example, Ross and Mary felt that her depression and unresolved family-of-origin issues were affecting her ability to function well as a parent and wife. They agreed that it would be helpful for her to become involved in a women's Bible Study group which would help support and encourage her in becoming more of a "woman of God." Instead, Mary experienced the group and its teachings as keeping her from overtly expressing her anger, discomfort, and emotional pain. She was told that she ought to be submissive, which included expressing only positive feelings. She increasingly suppressed troubling emotions related to past physical and sexual abuse, as well as those related to Ross's alcoholism, for fear of feeling guilt and shame at not being "God's Woman" and of being rejected and judged by family, friends, and fellow parishioners. Similarly, Ross placed a great deal of emphasis on the controloriented, patriarchal aspects of their church's teachings. Although he saw these as supporting his controlling stance within the family and his belief that his "unmanageable" life was under control, they served only to reinforce the problems within the couple relationship. The therapist explored these solutions (which seemed to have become part of the problems) with Ross and Mary in individual and conjoint sessions. Both husband and wife agreed that these beliefs and practices did not seem to be helpful and became increasingly open to exploring other possibilities within their belief system.

Dialogues regarding incongruent spiritual maps. This process involves discussions in which the therapist conceptualizes the situation as being exacerbated by a lack of fit between the person's spiritual map and his/ her present situation.

Clinical utility: This strategy is characterized by (a) underscoring the influence that thinking and languaging have on personal problems and (b) overtly challenging the clients to reexamine old beliefs and generate change from within.

Clinical example: Ross and Mary (see above) seemed to have become stuck in a dysfunctional pattern because of their religious beliefs. Consequently, they were challenged to reconsider their outmoded Biblical maps for living. These maps included their definitions of submission, authority, forgiveness, and repentance. The therapist emphasized the sacrificial-love quality of husband as head of home so that Ross could begin to let go of control. This seemed to be helpful because according to their spiritual and religious traditions, the male should be in control of the household, including his wife. The Biblical view of husband-wife relationships regarding co-parenting and sexuality was discussed. The therapist and the couple also explored the concept of grace, which facilitated a process of forgiving themselves (especially Mary regarding her drug abuse and past sexual abuses), each other, and eventually their families of origin. In other sessions, the metaphors of death, resurrection, and new life were utilized to encourage them to allow their old relationships and selves to "die" in order to gain new lives.

Note. The table is retrieved from Prest and Keller (1993), pp.142-144.

As an alternative to Prest and Keller's (1993) strategies based on the use of myth and metaphor, Hodge (2000) proposed the concept of "spiritual ecomap" that can be used in the evaluation, planning, and intervention process (see Figure 1). Hodge (2000) stated that the process of completing the spiritual map would provide the therapist with an opportunity to recognize the family's spiritual tradition before beginning any intervention. According to Hodge (2000), with the spiritual map, the illustrated representation of the family's existing spiritual relationships facilitates the transition from assessment to planning, spiritual powers can be clearly defined and used to overcome problems in other areas. Besides, the visual depiction of critical relationships in spiritual maps makes it easier to recommend various intervention methods (Hodge, 2000). 
Figure 1

Spiritual Ecomap

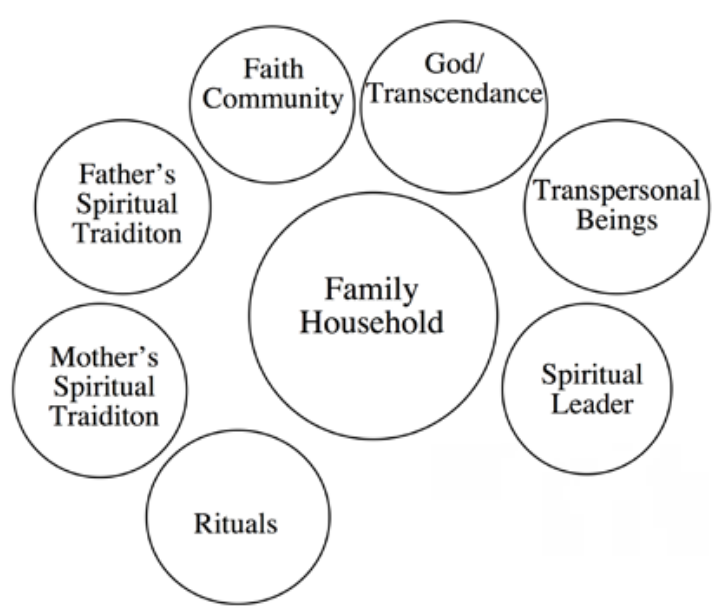

Note. The figure is retrieved from Hodge (2000), p. 222.

Similarly, Smith, and Harkness (2002) provided family therapists with several suggestions to help them incorporate spirituality into the process of structuring and delivering psychological services and interventions. Information suggested by them is summarized in the following:

(1)First of all, the therapist needs to reflect on his/her spiritual and religious understanding and prejudices, because the therapist must be aware of how his/her belief system affects or differentiates from the client's system.

(2)For the client's spiritual concerns to be properly addressed during the therapy process, it may be necessary to ask the client for permission to talk to the religious leader or spiritual counselor of the group to which he/she is a member. Religious leaders and spiritual counselors have often disregarded as a resource in family therapy practices, but it is important to note that many families may request spiritual guidance in addition to family therapy.

(3) Therapeutic progress may be decelerated or prevented if the leader in question and therapist provide conflicting information. Collaborating with the spiritual and religious leaders can strengthen the client's reliance on the therapeutic process. It also helps the therapists to demonstrate their knowledge of the client's support systems.

(4) Sometimes, clients may be worried about being evaluated by others due to their low commitment to spiritual or religious practices and poor belief systems. At this point, evaluating the religion or secular spirituality of the client with empathy and understanding is important in encouraging the client to share his/her spiritual stories. 
(5) The therapist's awareness that certain spiritual issues are beyond their expertise is important. For example, a family therapist is not the person who interprets scriptures or forgives sins for the client.

The main objectives of the spiritual assessment are to support and improve the spiritual well-being and development of families, to distinguish spiritual distress and its impact on overall family health, and to identify ways to include family spirituality while providing care (Tanyi, 2006). Accordingly, Walsh (2009a, p. 39) has proposed some questions that can be used to explore the spiritual dimension of the individual, couple and family experience within a more systematic structure. These questions specifically emphasize the focus on exploring ways in which spiritual beliefs and experiences may cause current distress and exploring ways in which past, current or potential spiritual resources can be used to alleviate distress, solve problems, and strengthen resistance (see Table 2).

Table 2

Exploring the Spiritual Dimension: Sources of Distress and Resources for Well-being, Healing, and Resilience

Start by grounding in individual, couple, and family experience of religion/spirituality:

1. Religious identification, affiliation-Organized, institutionalized faith tradition: Beliefs, practices, congregational involvement

2. Spirituality: Personal faith, transcendent values, practices within and/or outside religion (e.g., through prayer, meditation, nature, creative arts, service/activism). Include cultural influences (e.g., indigenous spiritual beliefs and practices)

- What role do religion and/or spirituality play in your life?

- Importance in daily living; shared in couple/family practices?

- In dealing with life challenges?

- In the past? In family of origin?

- Desire for greater spiritual dimension in life?

- How are couple or family religious/spiritual differences handled and accepted?

Explore religious/spiritual sources of distress:

- Is there couple or family conflict or cutoff over spiritual matters (e.g., with interfaith marriage and/or conversion; marriage and family standards; divorce, abortion or end-of-life decisions)?

- Have religious/spiritual convictions contributed to suffering (e.g., concerns about sin, punishment, afterlife) or been experienced as oppressive, harmful (e.g., sexist or heterosexist dogma, devaluation, abuse, or condemnation)?

- Have adversity, trauma, or injustice wounded the spirit?

- Has a spiritual void or cutoff from spiritual roots increased suffering or isolation?

Identify spiritual resources (religious and/or nonreligious):

- How do you find spiritual nourishment, connection, strength, meaning, inspiration? How might current, past, or potential spiritual resources support personal and relational well-being, healing, and resilience? Consider:

- Personal faith

- Relationship with God, Higher Power, Universal Spirit, Creator

- Contemplative practices (e.g., prayer, meditation, rituals)

- Faith community - connection, involvement (worship, activities), support

- Spiritual guidance, counsel (by clergy, pastoral counselor, chaplain)

- Communion with nature

- Creative arts, music, literature (expression, appreciation)

- Service to others, activism 


\section{Therapists' Beliefs in the Role of Spirituality in Their Personal and Professional Life}

Spirituality is a matter of issue not only for clients but also for therapists working in cooperation with the client during the psychological help process. It is possible to see various studies in the literature emphasizing the importance of spirituality in the personal and professional lives of therapists (Bergin \& Jensen, 1990; Carlson, Kirkpatrick, Hecker, \& Killmer, 2002; Prest, Russel, \& D’Souza, 1999). For example, in a study conducted by Bergin and Jensen (1990) with clinical psychologists, psychiatrists, social workers, and marriage/family therapists, researchers found that the majority of field specialists had certain religious tendencies ( $80 \%$ ) and $41 \%$ of them regularly participated in religious activities. Besides, professionals' level of religious participation and lifestyle was surprisingly similar to the profile of the laypeople. Although the religious tendency and participation of the professionals represented a very high rate, it was found interesting that only $29 \%$ of the participants reported that spirituality and religion were important in clinical work. Bergin and Jensen (1990) described the discrepancy between the high ratio of religious participation in private lives and the low percentage of involvement of spirituality and religion in clinical practice as "the discrepancy........ may be due to the fact that training, education and practice currently provide little place for such considerations" (p. 6).

In order to investigate the attitudes toward spirituality in clinical practice, Prest et al. (1999) studied with 66 masters or doctoral level students taking classes in marriage and family therapy (MFT) programs accredited by AAMFT. The vast majority of the respondents stated that both spirituality and religion were important in their personal lives. All of the participants defined themselves as a spiritual person, and $72.6 \%$ stated that they strongly felt their spirituality. Similarly, about $66 \%$ of respondents reported regular participation in practices that help them to communicate with their spirituality. Prest et al. (1999) found that spirituality was an effective force for $76.5 \%$ of the participants in guiding them towards a career in MFT. Most of the graduate students $(75 \%)$ accepted the statement that "every person has a spiritual dimension that should be considered in clinical practice" and $60.7 \%$ accepted that "almost every kind of psychosocial problem has a spiritual dimension to it" (p. 71). However, the majority (78.4\%) disagreed with the statement that "if people followed God's will they would not have so many psychosocial problems" (p. 71). When students were asked about their clinical practice in which they integrated therapy and spirituality, they reported that they used a wide variety of practices to include spiritual concepts in the evaluation and intervention process, such as: using the spirituality of the clients in the development of coping skills $(68.8 \%)$, using the spiritual language or concepts (56.9\%), discussing the client's spiritual symbols $(80.3 \%)$, discussing the meaning of life and death with the client (80.5\%) and using spiritual issues to connect the client to others in the context of the community (64.7\%) (Prest et al., 1999). 
Similar to the study conducted by Prest et al. (1999) with graduate students, Carlson et al. (2002) investigated the therapists' beliefs about the role of spirituality in their personal and professional lives with 153 therapists who were members of AAMFT. $95 \%$ of therapists considered themselves a spiritual person, $94 \%$ stated to believe that spirituality is an important aspect of their personal life, and $96 \%$ stated to believe that there is a relationship between spiritual health and mental health. Regarding the importance of integrating spirituality into clinical practice, $48 \%$ of the participants stated to agree with the statement "it is usually necessary to work with a client's spirituality if you expect to help them" (p. 162). 62\% of respondents stated to believe that "every person has a spiritual dimension that should be considered in clinical practice", $84 \%$ stated to agree that it is appropriate to talk about spirituality in a professional context (p. 162). About incorporating spirituality into the therapist's training process, $60 \%$ of the participants stated to believe that marriage and family therapists should receive training and supervision on spiritual matters, and 53\% said to believe that spirituality classes should be given as part of marriage and family therapy training.

More up-to-date research on the study of views on integrating spirituality into the MFT training process was conducted by Grams, Carlson, and McGeorge (2007) with 93 faculty members working in the undergraduate and graduate programs accredited by the Commission on Accreditation of Marriage and Family Therapy Education. Research findings revealed that faculty members of the MFT department agreed that spirituality has a role in their clinical work and professional life. $88.2 \%$ of the participants stated that it is appropriate for a family therapist to ask questions about client's spirituality, $92.5 \%$ of them found it appropriate for a family therapist to discuss the meaning of life, and $80 \%$ of them found it appropriate for a family therapist to discuss the spiritual experiences of a client. The vast majority of faculty members $(86.4 \%)$ reported that it is important for students to learn how to integrate spirituality into the clinical assessment process. In addition, $81.3 \%$ of the academicians expressed their wish that students should receive supervision and training on spiritual matters and $78 \%$ stated that spirituality should be included in the standard MFT training curriculum. Grams et al. (2007) also stated that some of the faculty members (66.7\%) had already integrated spirituality into the classes they taught.

Findings from various studies have shown that spirituality has considered as an important subject in both personal and professional life by students, faculty members and clinical practitioners working in the field of couple, marriage and family therapy. However, it would not be wrong to say that there are uncertainties regarding the integration of this issue into the clinical practice and training process. In a study comparing the beliefs of the couple and family therapists (CFT) accredited by AAMFT and CFT faculty members, both groups agreed on the importance of spirituality in their personal and professional lives (Carlson, McGeorge, \& Anderson, 2011). However, 
they shared hesitation to refer to the topic of spirituality in the therapy process directly and to teach students to integrate spirituality into their therapy process (Carlson et al., 2011). Researchers have stated that this hesitation about directly dealing with spiritual issues in the therapy and training process may be due to the participants' belief that personal values should be separated from professional life (Carlson et al., 2011). At this point, the therapists need to have ethical consideration when integrating their spiritual values and the client's spiritual values into the psychological help process.

\section{Ethical Dimension in the Inclusion of Spirituality in the Clinical Process}

In family therapy, to use spirituality as an effective resource in the help process and provide a certain approach for the practitioners in the therapy process, it is important to consider several ethical issues at the point of dealing with the spiritual and religious issues that concern the client's belief system. Therefore, considering ethical issues in the inclusion of spirituality in the couple, marriage and family therapy training process will be beneficial for students to feel safe during the therapy process and to use the therapeutic skills effectively. For example, therapists who improperly share their beliefs with their clients because of their commitment to their spiritual and religious values may constitute some ethical problems (Prest \& Keller, 1993).

In some cases, the therapist and client can share similar religious backgrounds and the therapist can make too many assumptions about what the religious beliefs, practices, and scriptures mean for the client, which in turn result in problem (Helmeke \& Bischof, 2002). According to the AAMFT Code of Ethics (2015) "marriage and family therapists are aware of their influential positions with respect to clients, and they avoid exploiting the trust and dependency of such persons". If the therapists use their effective positions in such a way, this situation can constitute an ethical problem. In the study conducted by Grams et al. (2007), faculty members of MFT declared their preferences for fewer interventionist practices if spirituality was integrated into the psychological assistance process. For example, although they considered that it was appropriate to ask clients about their spirituality or discover the spirituality of their clients, they did not find it appropriate for professionals to help clients to find and develop their spiritual way or to discuss the therapist's spirituality (Grams et al., 2007). Another ethical issue that can be addressed is the professionals who try to impose spiritual and religious beliefs on their clients. These psychological counselors or therapists may face the violation of the requirement of "non-discrimination" of the AAMFT Code of Ethics (2015), since a client's "religion" is considered as a protected category, just like sexual identity and race categories. At this point, therapists need to be in contact with their beliefs, to avoid imposing their values and individual agendas to the client (Harris, 1998). 
Spirituality can provide a positive effect on the therapy process by helping the client to understand the source of the problem better, to know the client better or to provide various resources for solving the client's problems (Prest \& Keller, 1993). However, it is also important for a therapist to consider the possible negative and harmful effects of the spiritual and religious beliefs that clients have in the process of making sense of self and struggles for life (Griffith \& Griffith, 2002; Walsh, 2009c). For example, even though a client should seek medical help, he/she may refuse to take medication to prove that he/she did not doubt God's power and he/she may want to honor his/her beliefs that he/she should only leave the healing process to God's hands (Griffith \& Griffith, 2002). This situation may result in both emotional and physical harm (Griffith \& Griffith, 2002). Another client who felt darkness spread in his life after his wife's death may think that "I thought God never brought anything on us that we cannot bear" and he may interpret his situation as "God abandoned me" (Prest \& Keller, 1993). In another case, a father, because of his spiritual and religious beliefs about sexual orientation, may reject his child who identifies himself as lesbian, gay or bisexual (Carlson, McGeorge, \& Toomey, 2014). In each of the situations above, it is important for the therapist, together with the clients, to investigate to what extent the clients' interpretation of their spiritual and religious beliefs contribute to the emergence of the problems they face (Carlson et al., 2014). In addition to the client, professionals should also consider ways to protect themselves during this process. By monitoring, organizing, and improving their subjective experiences, they can prevent potential personal and professional risks (Coffey, 2002). Also, practitioners can have training on spirituality to help a wider diversity of clients and support their potential levels of competence, so they can gain new perspectives on how to develop and regulate their own lives (Coffey, 2002).

\section{Conclusion}

Spirituality is an important aspect of human life. Recent studies have shown that spirituality has a significant impact on family functioning and family life satisfaction. In this section, dynamics between family members (the relationship between spouses, parent-child relationship, etc.) are examined within a spiritual context. At this point, the paradoxical effect of spirituality in family relationships draws attention. In other words, while spirituality can be a source of problems in family relations, it can also offer alternative options for solving problems. Seeing that spirituality is such an important issue in family relations, this chapter focuses on the integration of spirituality into family-oriented psychological help processes. Spiritually oriented psychological counseling and therapy are emerging fields in Turkey. By bringing a family-oriented approach to the spiritually oriented psychological help process, it is aimed to offer a new perspective to field practitioners working with couples and families. In the following sections of the book, various issues related to the family 
system in psychological counseling and therapy processes will be reviewed with a spiritually oriented approach.

\section{Acknowledgement}

This article does not involve any human participant data, and thus no ethical approval was required.

\section{References}

Abbott, D. A., Berry, M., \& Meredith, W. H. (1990). Religious belief and practice: A potential asset in helping families. Family Relations, 39(4), 443-448.

American Association for Marriage and Family Therapy (2015). Code of ethics. Retrieved from http://www.aamft.org/imis15/Content/Legal_Ethics/Code_of_Ethics.aspx

Anderson, D. A., \& Worthen, D. (1997). Exploring a fourth dimension: Spirituality as a resource for the couple therapist. Journal of Marital and Family therapy, 23(1), 3-12.

Bailey, C. E. (2002). The effects of spiritual beliefs and practices on family functioning: A qualitative study. Journal of Family Psychotherapy, 13(1-2), 127-144.

Bergin, A. E., \& Jensen, J. P. (1990). Religiosity of psychotherapists: A national survey. Psychotherapy: Theory, Research, Training, 27(1), 3-7.

Carlson, T. D., Kirkpatrick, D., Hecker, L., \& Killmer, M. (2002). Religion, spirituality, and marriage and family therapy: A study of family therapists' beliefs about the appropriateness of addressing religious and spiritual issues in therapy. American Journal of Family Therapy, 30(2), 157-171.

Carlson, T. S., McGeorge, C. R., \& Anderson, A. (2011). The importance of spirituality in couple and family therapy: A comparative study of therapists' and educators' beliefs. Contemporary family therapy, 33(1), 3-16.

Carlson, T. S., McGeorge, C. R., \& Toomey, R. B. (2014). Establishing the validity of the spirituality in clinical training scale: Measuring the level of integration of spirituality and religion in family therapy training. Contemporary Family Therapy, 36(2), 310-325.

Carothers, S. S., Borkowski, J. G., Lefever, J. B., \& Whitman, T. L. (2005). Religiosity and the socio emotional adjustment of adolescent mothers and their children. Journal of Family Psychology, $19(2), 263-275$.

Coffey, A. D. (2002). Spirituality: Lives and relationships in family-therapy concepts and practices. Journal of family psychotherapy, 13(1-2), 29-52.

Dollahite, D.C., Marks, L.D., \& Goodman, M. (2004). Families and religious beliefs, practices, and communities: Linkages in a diverse and dynamic cultural context. In M.J. Coleman \& L.H. Ganong (Eds.), The handbook of contemporary families: Considering the past, contemplating the future (pp. 411-430). Thousand Oaks, CA: Sage.

Dudley, M. G., \& Kosinski, F. A. (1990). Religiosity and marital satisfaction: A research note. Review of Religious Research, 32(1), 78-86.

Grams, W. A., Carlson, T. S., \& McGeorge, C. R. (2007). Integrating spirituality into family therapy training: An exploration of faculty members' beliefs. Contemporary family therapy, 29(3), 147-161.

Griffith, M. E., \& Griffith, J. L. (2002). Addressing spirituality in its clinical complexities: Its potential for healing, its potential for harm. Journal of Family Psychotherapy, 13(1-2), 167-194.

Helmeke, K. B., \& Bischof, G. H. (2002). Recognizing and raising spiritual and religious issues in therapy: Guidelines for the timid. Journal of Family Psychotherapy, 13(1-2), 195-214. 
Hodge, D. R. (2000). Spiritual ecomaps: A new diagrammatic tool for assessing marital and family spirituality. Journal of Marital and Family Therapy, 26(2), 217-228.

Kacerguis, M. A., \& Adams, G. R. (1980). Erikson stage resolution: The relationship between identity and intimacy. Journal of Youth and Adolescence, 9(2), 117-126.

Klein, D. M. \& White, J. M. (1996). Family theories: An introduction. Thousand Oaks, CA: Sage.

Lyons, L. (May 31, 2005). Faith accompanies most Americans through life. Retrieved from www. gallup.com/poll/16522/faith-accompanies-most-americans-through-life.aspx

Mahoney, A., Pargament, K. I., Tarakeshwar, N., \& Swank, A. B. (2008). Religion in the home in the 1980s and 1990s: A meta-analytic review and conceptual analysis of links between religion, marriage, and parenting. Journal of Family Psychology, 15(4), 559-596.

Marcia, J. E. (1966). Development and validation of ego-identity status. Journal of personality and social psychology, 3(5), 551-558.

Marks, L. (2004). Sacred practices in highly religious families: Christian, Jewish, Mormon, and Muslim perspectives. Family Process, 43(2), 217-231.

Marsh, R., \& Dallos, R. (2001). Roman Catholic couples: Wrath and religion. Family Process, 40(3), 343-360.

Marterella, M. K., \& Brock, L. J. (2008). Religion and spirituality as a resource in marital and family therapy. Journal of Family Psychotherapy, 19(4), 330-344.

Myers, S. M. (2006). Religious homogamy and marital quality: Historical and generational patterns, 1980-1997. Journal of Marriage and Family, 68(2), 292-304.

Prest, L. A., \& Keller, J. F. (1993). Spirituality and Family Therapy: Spiritual Beliefs, Myths, and Metaphors. Journal of Marital and Family Therapy, 19(2), 137-148.

Prest, L. A., Russel, R., \& D'Souza, H. (1999). Spirituality and religion in training, practice and personal development. Journal of Family therapy, 21(1), 60-77.

Smith, A. L., \& Harkness, J. (2002). Spirituality and meaning: A qualitative inquiry with caregivers of Alzheimer's disease. Journal of family psychotherapy, 13(1-2), 87-108.

Snarey, J. R., \& Dollahite, D. C. (2001). Varieties of religion-family linkages. Journal of Family Psychology, 15(4), 646-651.

Snider, J. B., Clements, A., \& Vazsonyi, A. T. (2004). Late adolescent perceptions of parent religiosity and parenting processes. Family Process, 43(4), 489-502.

Tanyi, R. A. (2006). Spirituality and family nursing: spiritual assessment and interventions for families. Journal of Advanced Nursing, 53(3), 287-294.

Waite, L. J., \& Lewin, A. C. (2010). Religious intermarriage and conversion in the United States: Patterns and changes over time. In C. Ellison ve R. Hummer (Eds.), Religion, families, and health in the United States: New directions in population-based research (pp.148-163). New Brunswick, NJ: Rutgers University Press.

Walsh, F. (2006). Belief Systems; The Heart and Soul of Resilience. In F. Walsh (Ed.), strengthening family resilience (2nd ed.) (pp. 49-83). New York: Guilford Press.

Walsh, F. (2009a). Integrating spirituality in family therapy: Wellsprings for health, healing, and resilience. F. Walsh (Ed.), Spiritual Resources in Family Therapy (2nd ed.) (pp. 31-64). New York: Guilford Press.

Walsh, F. (2009b). Preface. In F. Walsh (Ed.), Spiritual resources in family therapy (2nd ed.) (pp. xi-xv). New York: Guilford Press

Walsh, F. (2009c). Religion, spirituality, and the family: Multifaith perspectives. In F. Walsh (Ed.), Spiritual resources in family therapy (2nd ed.) (pp. 3-30). New York: Guilford Press.

Walsh, F. (2012). The spiritual dimension of family life. In F. Walsh (Ed.), Normal family processes: Growing diversity and complexity (4th ed.) (pp. 347-372). New York: Guilford Press. 